\title{
Antibacterial and Antifungal Properties of Persicaria Odorata Leaf Against Pathogenic Bacteria and Fungi
}

\author{
Muhd Ridzuan Pauzi ${ }^{1, *}$, Hairul Aini ${ }^{1}$, Norazian $^{2}$ and Anis Shah ${ }^{3}$ \\ ${ }^{I}$ Department of Basic Medical Sciences, Kuliyyah of Medicine, International Islamic University Malaysia,25200 \\ Kuantan, Malaysia; ${ }^{2}$ Department of Pharmaceutical Chemistry, Kuliyyah of Pharmacy, IIUM; ${ }^{3}$ Department of Internal \\ Medicine, Kuliyyah of Medicine, International Islamic University Malaysia, 25200 Kuantan, Malaysia; \\ E-mail: ridzuan_pauzi@yahoo.com
}

Persicaria odorata is a common plant and well known locally as "daun kesum" that is usually used in culinary and have various medicinal properties. This study is conducted to investigate the antimicrobial activity and the chemical constituent of the most active extract. The leaves were extracted using n-hexane, dichloromethane, methanol and water to produce the respective extracts. All extracts were tested against eight bacterial strains which include gram positive and gram negative bacteria and one fungal strain by using disc diffusion method. In this research erythromycin $15 \mu \mathrm{g}$, vancomycin $30 \mu \mathrm{g}$ and gentamicin $10 \mu \mathrm{g}$ were used as antibacterial standard whereas miconazole $50 \mu \mathrm{g}$ were used as antifungal. The antimicrobial activity of the active extract is evaluated quantitatively by using broth microdilution assay. Gas Chromatography-Mass (GCMS) Spectroscopy analysis was used to analyze the chemical constituent of the most active extract. n-Hexane extract was found to be the most active extract which was active against $S$. aureus (29.3 \pm 0.57$)$, S. epidermidis (32.6 \pm 1.52$)$, S. pneumonia $(11.3 \pm 1.52)$ and $S$. pyogenes $(15.6 \pm 1.15)$. However, the all extracts are inactive against fungi. The extract produced minimum inhibitory concentration (MIC) of $100 \mu \mathrm{g} / \mathrm{ml}$ against $S$. aureus and $50 \mu \mathrm{g} / \mathrm{ml}$ each against S. epidermidis, S. pneumonia and $S$. pyogenes. GCMS analysis has identified Decanal, Caryophyllene, Dodecanal the major constituents of $n$-hexane extract. The results obtained in this study showed that $P$. odorata leaves have high potential to be used as natural antibacterial agent against bacterial infections.

Keywords: Persicaria odorata, Antibacterial activities, physicochemical properties. 